\title{
Wages of Information Technology Professionals - A Czech and Slovak Republic Case
}

DOI: 10.12776/QIP.V25I1.1468

\author{
Luboš Marek, Petr Doucek, Lea Nedomová
}

Received: 2020-06-07 Accepted: 2021-03-19 Published: 2021-03-31

\begin{abstract}
Purpose: The objective of this article is to compare the trend in wages of ICT Professionals in the Czech and Slovak economies during the past two decades.

Methodology/Approach: The input data set for ICT Professionals was relatively large - over 2.2 million (of which ICT represented over 60 thousand) in the Czech Republic and 1.1 million (of which ICT represented over 24 thousand) in the Slovak Republic. For the purposes of presented analyses, we used basic statistical methods and characteristics.

Findings: We can make the following general conclusions based on our analyses: all analyzed wage characteristics increased over time, with the exception of the economic crisis during 2009-2014 when they stagnate.

Research Limitation/Implication: Our data include outliers, especially wages above EUR 4,000. However, these wages, which are relatively rare, significantly influence the total volume of wages.

Originality/Value of paper: Analysis of our data offers information about development of average real wages in ICT oriented jobs. There can be found analysis of wages in all sectors in literature. Analysis of ICT Professionals wages is rarely published in journals.
\end{abstract}

Category: Research paper

Keywords: digital economy; ICT Professionals; wages in ICT; trends in wages development 


\section{INTRODUCTION}

The present, even according to politicians, economists and managers of multinational companies, can be characterized as a turbulent time during which digitalization has significantly strengthened. Different levels of management or sectors of the economy have different ideas about what digitalization actually is. The public administration promotes the concept of e-government, the municipalities promote the concept of smart cities, while industrial enterprises are implementing a new concept of production - the so-called Industry 4.0 (Basl and Doucek, 2019). The main objective of this trend is the digitization, robotization and automation of production (Mař́k deployment of information and communication technologies (ICT) in the life cycle of products, from their design, through their development, implementation and use all the way to their final disposal. This closed life cycle of products or services leads to a very topical concept of a so-called "Circular Economy". Its relations to Industry 4.0 are described in more detail e.g. in (Tseng, et al., 2018).

Integration and further expansion of ICT into the economic and everyday life of people depends, among other things, on the number and qualifications of ICT Professionals. There is no company, office, ministry or institution that can do without IT (Malá, 2015). The ICT profession is a prerequisite for the successful operation of each of the mentioned institutions. There is a constant demand for, and a great interest in, these workers on the labour market.

If we want to gradually switch to a digital economy, we will need to have enough qualified ICT Professionals (Hanclova et al., 2014). Their financial remuneration should correspond to their important role in the economy (Mysikova and Vecernik, 2018). We can expect that it is much higher than the average remuneration in the entire economy (Doucek, Nedomova and Maryska, 2015). Without higher remuneration of key ICT Professionals, it is not possible to build a digital economy. To verify this fact in the small, open economies of the Czech Republic and the Slovak Republic, we have analyzed the trend in wages of ICT Professionals in both countries over the past 19 years.

The need for qualified workers for digital transformation and the need for their adequate remuneration in the Czech Republic is addressed in particular by Mař́k (2016). Other designers of digital economy and Industry 4.0 models also focus on the relationship of the digitalization of the economy, the need for qualified workers and their remuneration - i.e. their wages. It mainly concerns studies on the German Industry 4.0 model (Wang, Towara and Anderl, 2017; Suri et al., 2017) at its macroeconomic level. Although society is expected to grow after the implementation of digitalization at the macroeconomic level, it is interesting to note that job opportunities and wages in this field do not grow accordingly. Torrent-Sellens (2008) and the conclusions of his study confirm this fact especially in terms of an increase in job opportunities and wages in various ICT professions. The wages of ICT Professionals tend to be higher than average wages in economies (Torrent-Sellens, 2008; Marek and Doucek, 2016); this fact 
also opens up the issue of equal pay for equal work - that is, the issue of equality in remuneration for ICT Professionals' work not only in the economy but also in heterogeneous work teams comprising of men and women (Simard et al., 2014).

The objective of this article is to compare the trend in wages of ICT Professionals in the Czech and Slovak economies during the past 19 years. We will compare the average wage of ICT Managers, ICT Specialists and ICT Technicians with the average wage of the relevant country and with the average for all aforesaid categories. We will also analyze average wages in the first and ninth deciles in 2018.

\section{METHODOLOGY}

\subsection{Data Collection and Processing}

We used to select data from the Average Earnings Information System (AEIA). Based on the source (ISPV, 2020), it is a system that regularly monitors the earnings and work hours of employees in the Czech Republic. The Average Earnings Information System contains data obtained from regular statistical surveys called the "Average Earnings Quarterly Survey", which are included in the statistical survey program announced by the Czech Statistical Office in the collection of laws for the relevant calendar year.

The Average Earnings Quarterly Survey is harmonized with the structural survey of the European Union called the Structure of Earnings Survey (see Commission Regulation (EC) No. 1916/2000 as amended). We analyzed the gross monthly wage or salary and hourly earnings as well as the individual components of the gross monthly wage (salary), i.e. bonuses, extra pays and reimbursements. The gross monthly wage in our data group was calculated as a multiple of hourly earnings in the second quarter and average monthly working hours for each year. We rounded off the average working hours to a whole number. We analyzed the number and structure of hours worked (e.g. overtime) and not worked (e.g. sickness and vacation). The AEIA includes the Labor Cost Regional Statistics providing detailed information about wage gaps in the individual regions of the Czech Republic. The administrator of the Average Earnings Quarterly Survey is the Ministry of Labor and Social Affairs. The survey and its progress are overseen by a commission composed of the representatives of the Ministry of Labor and Social Affairs, the Czech Statistical Office, the Ministry of Finance, the Czech National Bank, the Bohemian-Moravian Confederation of Trade Unions, the Confederation of Industry and Transportation of the Czech Republic, CERGE EI, the University of Economics in Prague and other institutions. The private data were provided by the Czech and Slovak company Trexima, two different firms with the same name.

The data have a relatively detailed structure; wage bands, in which absolute frequencies are analyzed, are set at 20 EUR each. 
The trend in wages in the Czech Republic and the Slovak Republic is very similar. Of course, the wages of ICT Professionals increase over time. These are data for two countries with different currencies and different inflation. First, we had to adjust these data for inflation. We used inflation data shown on the websites of the national statistical offices (CZSO, 2020a; SUSR, 2020). After that, we converted the data in CZK to EUR, using the exchange rate of the Czech National Bank. We also had to recalculate Slovak wages before the year 2009 since the Slovak Republic did not switch to EUR until the year 2009. For the conversion, we used the exchange rates of the Czech National Bank (CNB, 2020) and the Slovak National Bank (NBS, 2020). The input data set for the analyses was relatively large. The number of wages analyzed in the last year 2018 was as follows: over 2.2 million (of which ICT represented over 60 thousand) in the Czech Republic and 1.1 million (of which ICT represented over 24 thousand) in the Slovak Republic.

\subsection{Categories of ICT Professionals}

We used the internationally recognized ISCO (CZSO, 2020b) to classify the occupation of ICT Professionals. Both countries switched to this classification in 2009 and are using it now. Based on this classification, the occupation of ICT Professionals is divided into the following three main groups (CZSO, 2020b):

- ICT Managers (ISCO 133) (hereinafter as the ICT 133 category);

- ICT Specialists (ISCO 25) (hereinafter as the ICT 25 category); and

- ICT Technicians (ISCO 35) (hereinafter as the ICT 35 category).

ICT Managers (ISCO 133) - plan, manage and coordinate the purchases, development, maintenance and use of computer and telecommunication systems. They work in management sections or as CEOs of an enterprise or organization that has no management hierarchy (CZSO, 2020b).

ICT Specialists (ISCO 25) research, plan, design, write, test, provide consultations and improve IT, hardware, software and related concept systems for specific applications; process related documentation, including policies, principles and procedures; design, develop, supervise, maintain and support databases and other information systems to ensure their optimal performance and data integrity and security. Most occupations in this class require university skills and knowledge (CZSO, 2020b).

ICT Technicians (ISCO 35) support the regular operation of computer and communication systems and networks and perform technical tasks related to telecommunications and to the transmission of image, sound and other types of telecommunications signals on land, on the sea or in the air. Most occupations in this class require high school skills and knowledge (CZSO, 2020b).

This article focuses only on these three categories of ICT Professionals represented in ISCO as ISCO 133, ISCO 25 and ISCO 35. The article does not 
analyze the wages of ICT academicians and researchers. We only focus on the professions that have an immediate impact on the number of ICT Professionals in the Czech economy and in the Slovak economy.

\subsection{Processing Methods}

For the purposes of our analyses, we used only basic statistical methods and characteristics. Since the average is the most common wage characteristic, we worked mainly with the average wage. Since the average is sensitive to outliers, it was necessary to mention and compare other statistical locations, especially quantiles. Our data include outliers, especially wages above EUR 4,000. However, these wages, which are relatively rare, significantly influence the total volume of wages (Marek and Doucek, 2016). In our case, they significantly increase the average wage. Our article also includes a quantile analysis.

We used MS Excel statistical functions to process our data and provide our tables and figures.

\section{RESULTS}

\subsection{Average Wages of ICT Professionals}

First, let's examine average wages. The trend in average wages is shown in Table 1, Figure 1 and Figure 2.

For the purposes of comparison, we show average wages in each analyzed republic (CR - Czech Republic, SR - Slovak Republic) without the wages of ICT Professionals, the average wages of ICT Professionals in both republics (Average ICT CR in the Czech Republic and Average ICT SR in the Slovak Republic), the wages of ICT Managers (133 CR in the Czech Republic and 133 SR in the Slovak Republic), ICT Specialists (25 CR in the Czech Republic and 25 SR in the Slovak Republic), and ICT Technicians (35 CR in the Czech Republic and 35 $\mathrm{SR}$ in the Slovak Republic).

Table 1 - Average Wages

\begin{tabular}{|l|c|c|c|c|c|c|c|c|c|c|}
\hline Year & $C R$ & $\begin{array}{l}\text { Average } \\
\text { ICT CR }\end{array}$ & 133 CR & $25 C R$ & $35 C R$ & $S R$ & $\begin{array}{l}\text { Average } \\
\text { ICT SR }\end{array}$ & 133 SR & 25 SR & 35 SR \\
\hline 2000 & 530 & 897 & 1,391 & 845 & 822 & 534 & 850 & 1,335 & 921 & 658 \\
\hline 2001 & 621 & 1,054 & 1,615 & 986 & 972 & 517 & 803 & 1,167 & 850 & 703 \\
\hline 2002 & 715 & 1,186 & 1,840 & 1,130 & 1,089 & 562 & 942 & 1,331 & 1,059 & 754 \\
\hline 2003 & 732 & 1,204 & 1,830 & 1,166 & 1,117 & 575 & 917 & 1,453 & 1,011 & 750 \\
\hline 2004 & 749 & 1,208 & 1,978 & 1,152 & 1,131 & 590 & 876 & 1,525 & 847 & 811 \\
\hline 2005 & 830 & 1,384 & 2,228 & 1,345 & 1,280 & 623 & 1,090 & 1,774 & 1,145 & 910 \\
\hline
\end{tabular}




\begin{tabular}{|l|c|c|c|c|c|c|c|c|c|c|}
\hline Year & $C R$ & $\begin{array}{l}\text { Average } \\
\text { ICT CR }\end{array}$ & 133 CR & $25 C R$ & 35 CR & $S R$ & $\begin{array}{l}\text { Average } \\
\text { ICT SR }\end{array}$ & 133 SR & 25 SR & $35 S R$ \\
\hline 2006 & 890 & 1,475 & 2,524 & 1,466 & 1,334 & 685 & 1,216 & 2,075 & 1,336 & 927 \\
\hline 2007 & 950 & 1,713 & 2,962 & 1,659 & 1,583 & 784 & 1,440 & 2,292 & 1,577 & 1,017 \\
\hline 2008 & 1,095 & 1,971 & 3,371 & 1,941 & 1,793 & 913 & 1,591 & 2,671 & 1,774 & 1,144 \\
\hline 2009 & 1,018 & 1,829 & 3,096 & 1,780 & 1,689 & 956 & 1,723 & 2,827 & 1,842 & 1,319 \\
\hline 2010 & 1,080 & 1,769 & 3,092 & 1,857 & 1,499 & 976 & 1,775 & 3,037 & 1,897 & 1,360 \\
\hline 2011 & 1,113 & 1,809 & 3,181 & 1,896 & 1,513 & 1,000 & 1,811 & 3,051 & 1,982 & 1,323 \\
\hline 2012 & 1,089 & 1,780 & 3,146 & 1,855 & 1,454 & 1,006 & 1,866 & 3,822 & 1,917 & 1,284 \\
\hline 2013 & 1,038 & 1,726 & 3,106 & 1,785 & 1,417 & 996 & 1,816 & 3,285 & 1,925 & 1,190 \\
\hline 2014 & 976 & 1,644 & 3,039 & 1,705 & 1,342 & 1,025 & 1,878 & 3,535 & 1,964 & 1,214 \\
\hline 2015 & 1,004 & 1,718 & 3,071 & 1,797 & 1,386 & 1,067 & 1,980 & 3,647 & 2,066 & 1,273 \\
\hline 2016 & 1,060 & 1,813 & 3,269 & 1,894 & 1,459 & 1,116 & 2,033 & 3,777 & 2,119 & 1,291 \\
\hline 2017 & 1,138 & 1,932 & 3,522 & 2,029 & 1,528 & 1,175 & 2,065 & 3,507 & 2,157 & 1,371 \\
\hline 2018 & 1,249 & 2,079 & 3,690 & 2,184 & 1,630 & 1,243 & 2,151 & 3,624 & 2,246 & 1,421 \\
\hline
\end{tabular}

It is clear that wages in individual categories differ. Even wages in the same category in the Czech Republic and the Slovak Republic sometimes differ. Since there are too many numbers in Table 1, the following two figures (Figure 1 and Figure 2) will provide a much better and more detailed comparison.

The average wages in the legend are arranged from highest to lowest average wages. It is quite clear that the ICT 133 category in both countries maintained the highest wages during the entire period of 19 years. On the other hand, the national average was the lowest. It is important to mention that the national average wage does not include ICT wages. We will show how ICT increases the national average.

There is a very small difference in both countries between the ICT category (Average ICT, which is the average wage for entire ICT - i.e. ICT 133, ICT 25 and ICT 35 together) and the ICT 25 category (Average ICT 25). The ICT 35 category (Average 35) is also above the national average.

The order of individual categories is the same in both countries. However, individual categories differ in both countries. The average wage of ICT 35 was significantly higher in the Czech Republic for the entire time period of 19 years. The average wage of ICT 133 and 25 was higher (with some exceptions) in the Czech Republic during 2001-2011, but then the situation turned around and the average wage was higher in the Slovak Republic. The differences in 2018 were relatively small (certainly smaller than in previous years) and wages were basically the same. 


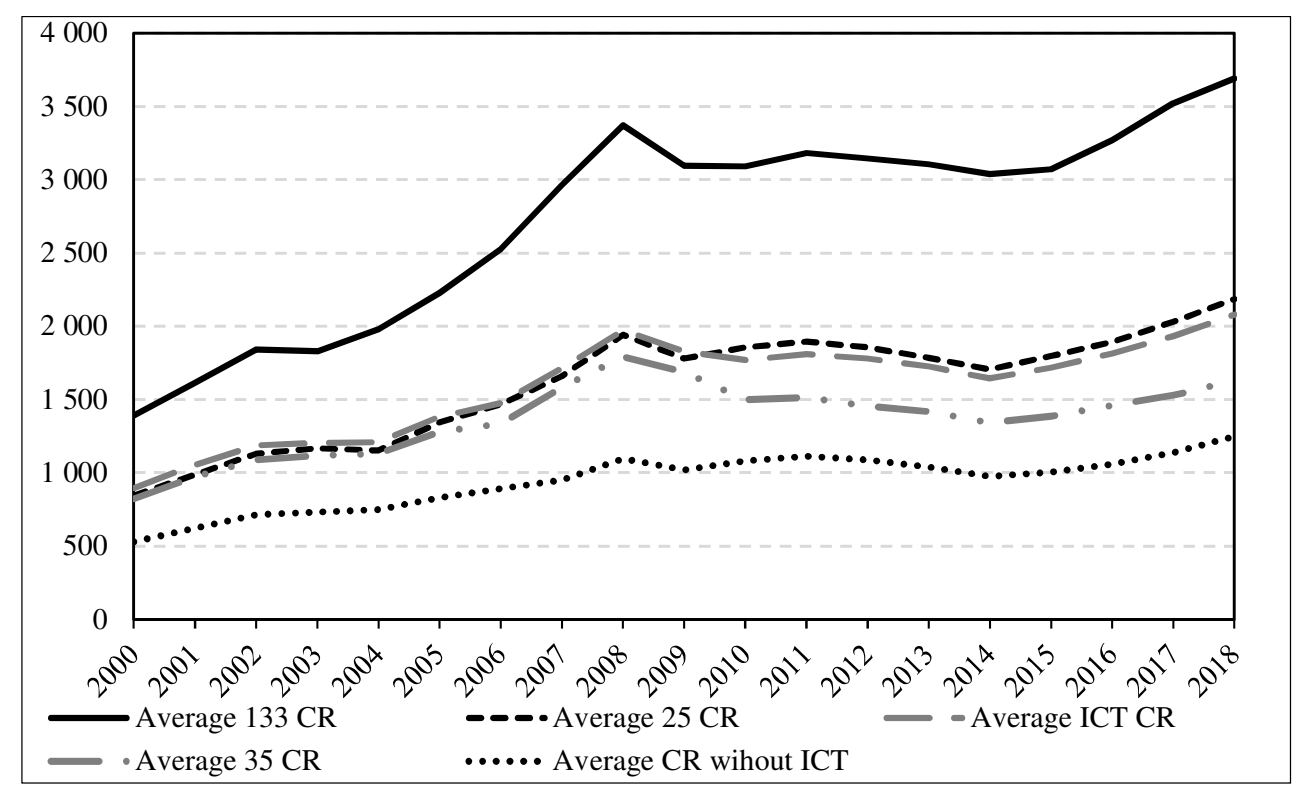

Figure 1 - Average Wages $-C R$

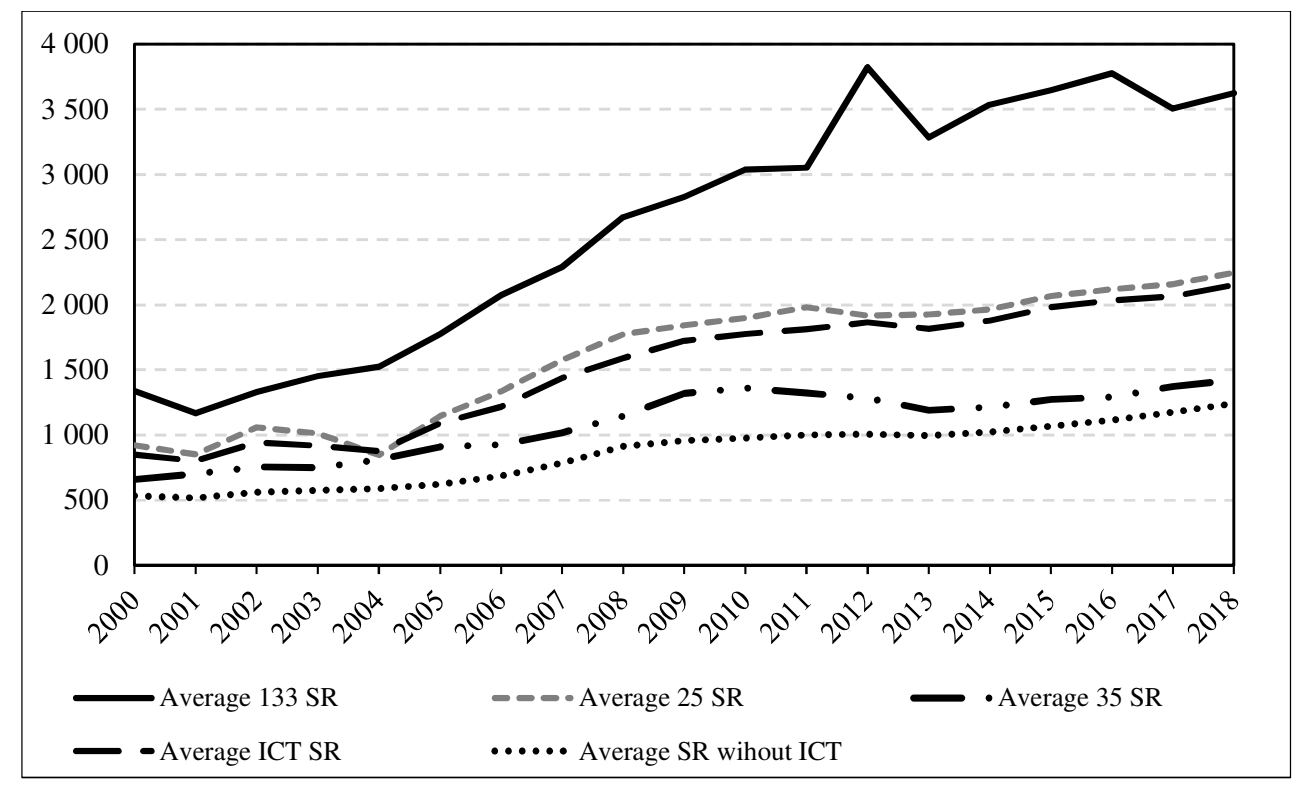

Figure 2 - Average Wages - SR

If we calculate the average of the differences in individual years, the data seem to be in favour of the Czech Republic. Average differences for the entire analyzed time period are shown in Table 2 . 
Table 2 - Differences between $C R$ and $S R$

\begin{tabular}{|c|c|c|c|c|}
\hline CR - SR & CR ICT - SR ICT & 133 CR -133 SR & 25 CR - 25 SR & 35 CR - 35 SR \\
\hline 81 & 72 & 117 & -9 & 280 \\
\hline
\end{tabular}

The ICT 35 category shows the biggest difference. Table 2 shows that ICT Professionals were paid better in the Czech Republic during the entire analyzed time period, with the exception of ICT Specialists who were paid a little bit better in the Slovak Republic in the long term. As mentioned above, the older data in the analyzed time series speak in favour of the Czech Republic. ICT Technicians were the only category where the Czech Republic showed higher wages for the entire analyzed time period.

Let's compare the average wage of ICT Professionals with the national average wage (we would like to point out again that this wage does not include ICT). The results are shown in Table 3.

Table 3 - ICT Categories as Compared to the Average National Wage

\begin{tabular}{|c|c|c|c|c|c|c|c|}
\hline ICT/CR & $133 / \mathrm{CR}$ & $25 / \mathrm{CR}$ & $35 / \mathrm{CR}$ & $\mathrm{ICT} / \mathrm{SR}$ & $133 / \mathrm{SR}$ & $25 / \mathrm{SR}$ & $35 / \mathrm{SR}$ \\
\hline 1.687 & 2.866 & 1.689 & 1.464 & 1.739 & 2.939 & 1.851 & 1.280 \\
\hline
\end{tabular}

We can say that the average wage of ICT Professionals is considerably higher than the national average wage in the Czech Republic and in the Slovak Republic. In the Czech Republic, it is higher by approximately 69\% and in the Slovak Republic by as much as $74 \%$. The ICT 133 category shows the highest average wage as compared to the national average. ICT Managers in the Czech Republic earn 2.78 times more than the average and in the Slovak Republic 2.94 times more. This means that their wages are almost three times higher than the average wage. The wages of the ICT 35 category and the ICT 25 category are also significantly higher than the average wage. Overall, we can say that ICT Professionals in both countries are paid very well as compared to other workers. The situation in Slovakia is more favourable for ICT because the three ICT categories, with the exception of the ICT 35 category, are better off in Slovakia.

Figure 1 and Figure 2 show that the average wage in different categories does not grow at the same rate. Therefore, we calculated the average growth coefficient for the entire time period of 19 years and showed the results in Table 4.

Table 4 - Average Growth Rate of Wages

\begin{tabular}{|c|c|c|c|c|c|c|c|c|c|}
\hline $\mathrm{CR}$ & ICT CR & $133 \mathrm{CR}$ & $25 \mathrm{CR}$ & $35 \mathrm{CR}$ & $\mathrm{SR}$ & ICT SR & $133 \mathrm{SR}$ & $25 \mathrm{SR}$ & $35 \mathrm{SR}$ \\
\hline 1.049 & 1.048 & 1.056 & 1.054 & 1.039 & 1.048 & 1.053 & 1.057 & 1.051 & 1.044 \\
\hline
\end{tabular}




\subsection{Quantile Analysis}

The average wage of the ICT 133 category grew the fastest - by $5.6 \%$ a year in the Czech Republic and by $5.7 \%$ a year in the Slovak Republic. The ICT 25 category is also doing well; the ICT 35 category is lagging behind the national growth rate. However, the situation in both countries is similar; there are no significant differences between individual categories.

The wages of $10 \%$ of the worst and best paid ICT Professionals (i.e. wages below the 10th percentile and above the 90th percentile) provide interesting information in Figure 3.

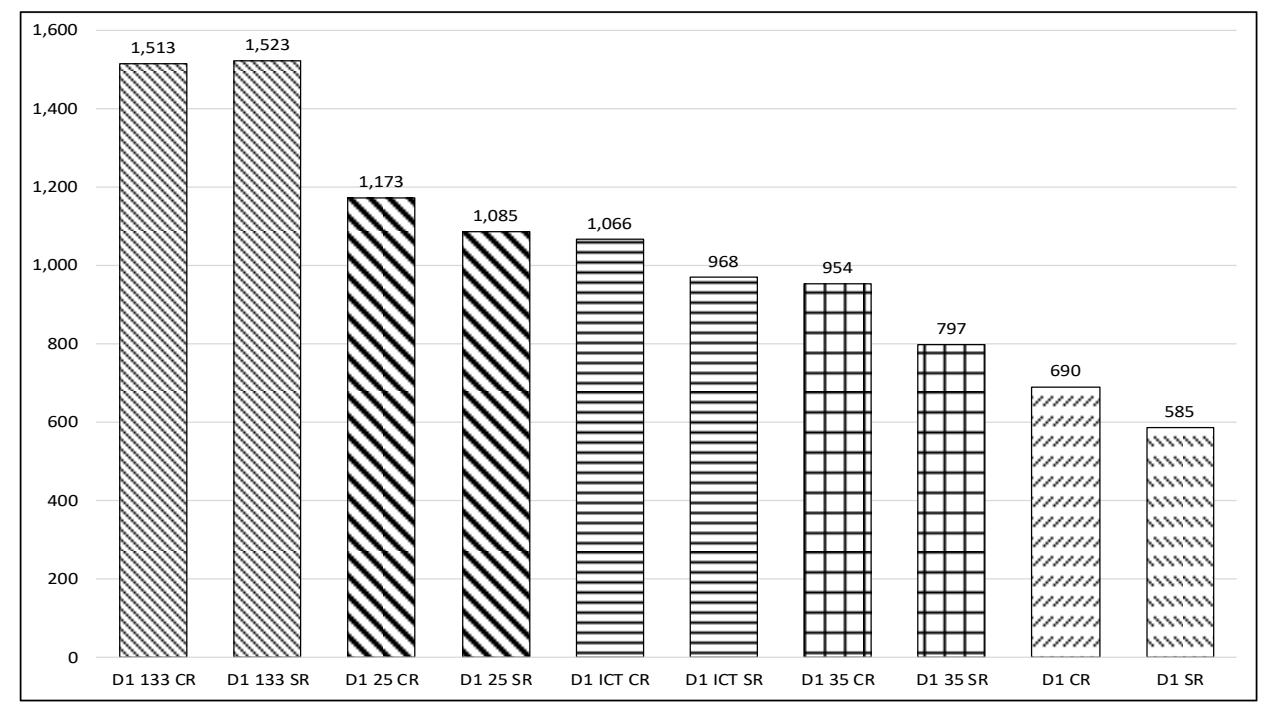

Figure 3 - 10\% Wage Quantile

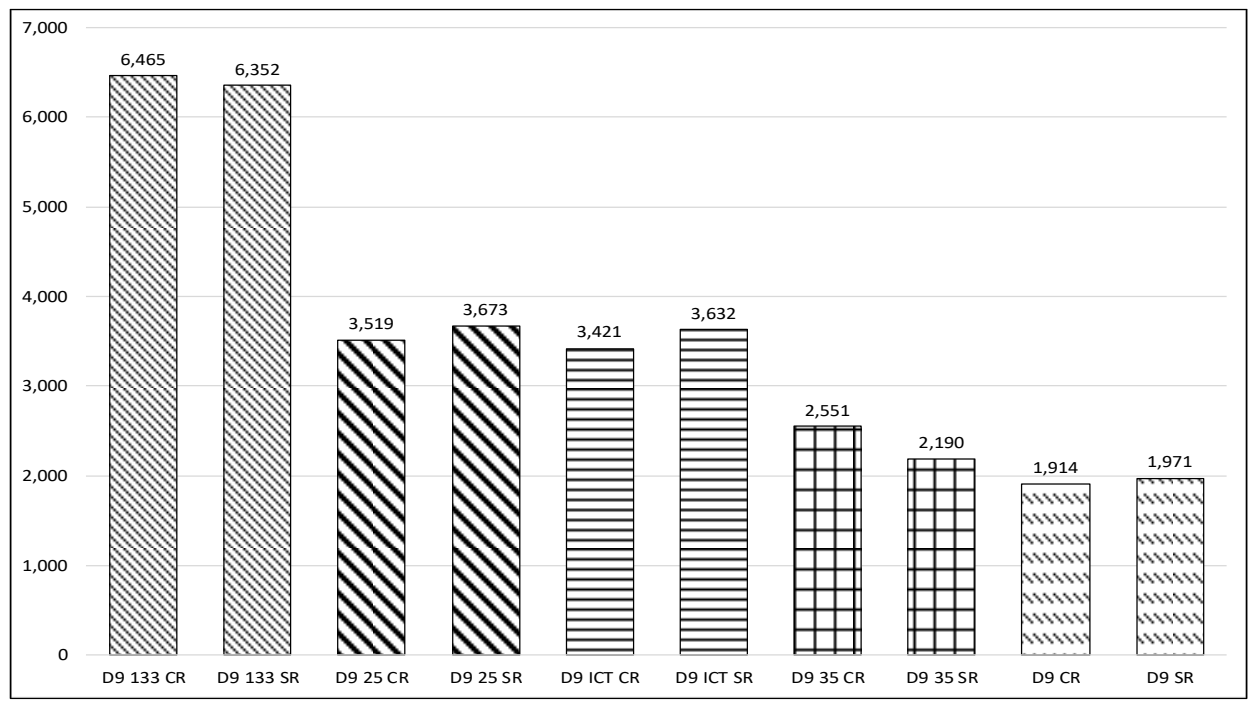

Figure 4-90\% Wage Quantile 
Figure 4 and Figure 5 compare only the values in 2018. The situation in previous years was similar in terms of comparison, but the values grew constantly over time, as was the case with the average wage. Except for the ICT 133 category, where the $10 \%$ quantile was almost the same (it differs by EUR 10 in favour of the Slovak Republic), the values in the Czech Republic were generally higher than in the Slovak Republic. There was a difference of about EUR 100 in the ICT 25 category, the ICT 35 category and at national levels. The biggest difference (approximately EUR 350) was in the ICT 35 category in favour of the Czech Republic.

Interestingly, even $10 \%$ of the worst-paid workers in the ICT 133 category seem to gain a wage (EUR 1,513 is a $10 \%$ quantile in the Czech Republic and EUR 1,523 in the Slovak Republic) that is higher than the national average wage (EUR 1,272 in the Czech Republic and EUR 1,421 in the Slovak Republic - this time, the average wage includes ICT).

Figure 4 shows $90 \%$ quantiles in all categories. This means that $10 \%$ of ICT Professionals gain wages higher than those displayed. The wage in the ICT 133 category is already very high in both countries and completely different from all other values. Wages in the ICT 25 category and at national levels are comparable. The situation in both countries is similar. The biggest difference between the two countries is again in the ICT 35 category.

Let's compare average and median wages. It is generally claimed that about $2 / 3$ of employees earn less than the average wage. Our data should confirm this claim, i.e. the average should be roughly a $67 \%$ quantile and therefore should be significantly higher. We calculated the difference between the average wage and the median wage. Again, this is a comparison for the year 2018 only, although we calculated the data for the entire analyzed period. The results are shown in Figure 5.

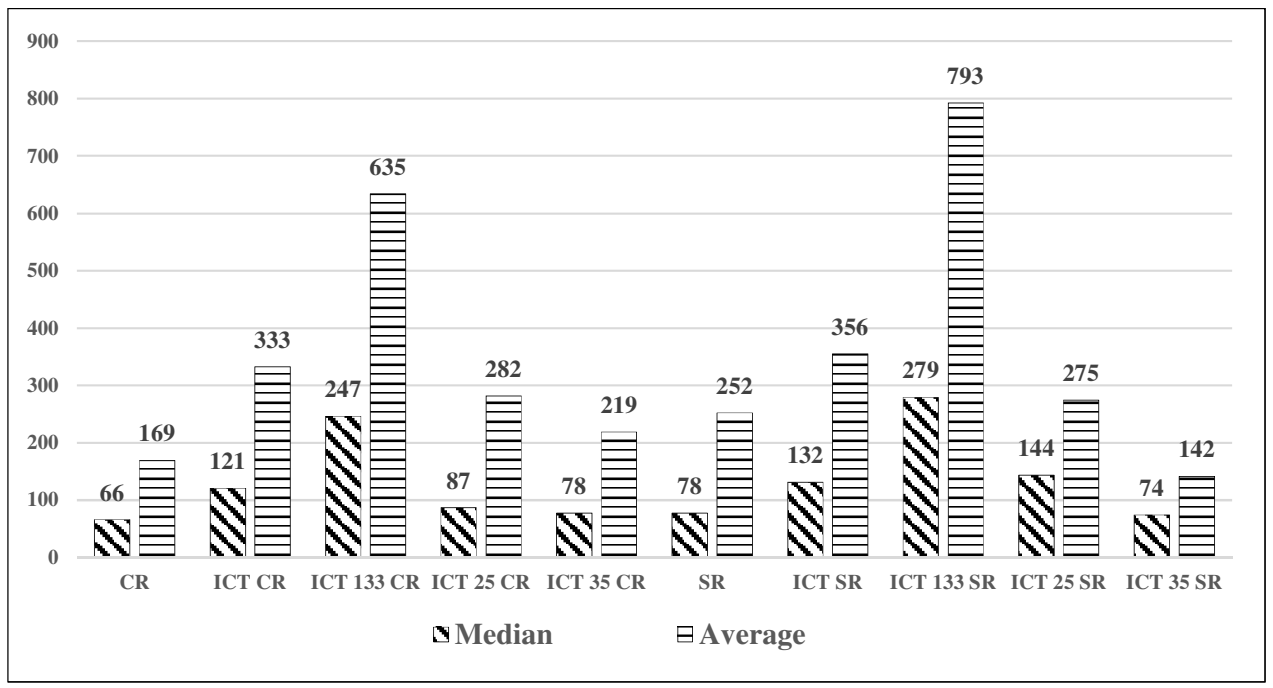

Figure 5 - The Difference between the Average and the Median 
The Figure 5 shows the differences between the average and the median. To make a time comparison, we chose the difference in the first analyzed year (2000) and the last analyzed year (2018). The differences for each category in the year 2000 are shown first, the differences in the year 2018 are shown second. The figure clearly shows that the gap between the median and the average is widening over time. The difference is quite striking in all categories in both countries. The difference between the median and the average increases absolutely the most in the ICT 133 category, and this difference is greater in the Slovak Republic.

\section{CONCLUSIONS}

The objective of the analysis was to compare the real wages of ICT Professionals in the Czech Republic and the Slovak Republic. We analyzed the three most important categories - ICT Managers, ICT Specialists and ICT Technicians. We used data sets containing the interval distribution of wage frequencies for the Czech Republic and the Slovak Republic. The average wage of all three categories of ICT Professionals was compared with the average wage in the Czech Republic and the Slovak Republic. We compared two main areas average real wages and wage quantiles. Based on our analyses, we can make the following general conclusions:

- All analyzed wage characteristics increased over time, with the exception of the economic crisis during 2009-2014 when they stagnate;

- There are large differences between individual categories of ICT Professionals, but the same categories in the Czech Republic and the Slovak Republic are very similar;

- All categories of ICT Professionals show significantly higher wages than national average wages;

- What was said about the average wage also applies to quantiles; the comparison between the Czech Republic and the Slovak Republic shows almost the same values in the same categories;

- The category of ICT Managers is particularly different since it shows an abnormal number of wages above EUR 4,000.

Another anomaly that needs to be explained are the significant deviations in the average wages of ICT Managers in the Czech Republic in 2008 and in the Slovak Republic in 2012. Both deviations have something in common and something different.

There was a significant shortage of qualified workers, including ICT Professionals, on the Czech labour market in 2008. For this reason, average wages in the entire Czech Republic grew faster this year than expected based on trend curves. The overall trend of the years before the year 2008 is shown in Figure 1. The 
subsequent economic crisis then lowered average wages in all analyzed categories as compared to the year 2008 .

On the Slovak market, the financial period of projects supported from European funds ended in 2012 and the Slovak Republic had a lot of unfinished ICT projects that lacked ICT managers or lacked good ICT managers. For this reason, EU funds were used to pay significantly higher wages to managers of state ICT projects. When the year 2012 ended and all EU funds were used up, the wages returned to their original level expected for the year 2009 based on the trend curve. Interestingly, the average wages of ICT Specialists and ICT Technicians dropped in 2008, while the average wage for all these categories went slightly up thanks to a high increase in the wages of ICT Managers.

In conclusion, we can say that there is no big difference in average wages between the Czech Republic and the Slovak Republic. All analyzed characteristics are very similar in both countries. The same situation is at the national level as well. Given the big difference between the average wage in all ICT areas in the Czech Republic and the Slovak Republic and the average wage in the entire economy of both countries, we can only say that working in ICT is very good from financially. This also creates an incentive especially for young people to work in ICT. Work in ICT is rewarded above average in both analyzed countries, which makes these professions interesting for people. It is a good thing that they are both for professionals mostly with a secondary education (ICT Technicians - ISCO 35) and for university-educated people (ICT Specialists - ISCO 25). ICT Managers (ISCO 133) are recruited from among either competent people with an appropriate education and experience or university-educated experts - typically project managers, software engineers, etc.

\section{ACKNOWLEDGEMENT}

The paper was processed with contributions from an institutional-support fund for long-term conceptual development of science and research at the Faculty of Informatics and Statistics of the University of Economics, Prague (IP400040).

\section{REFERENCES}

Average Earnings Information System (ISPV), 2020 ISPV - mzdy a platy podle profesí. [online] Available at: 〈https://www.ispv.cz> [Accessed 11 December 2020]

Basl, J. and Doucek, P., 2019. A Metamodel for Evaluating Enterprise Readiness in the Context of Industry 4.0. Information [e-journal], 2019, 10(3), 89. DOI: 10.3390/info10030089. 
Czech National Bank (CNB), 2020. Kurzy devizového trhu - Česká národní banka. [online] Available at: <https://www.cnb.cz/cs/financni-trhy/devizovytrh/kurzy-devizoveho-trhu/kurzy-devizoveho-trhu/> [Accessed 6 December 2020].

Czech Statistical Office (CZSO), 2020a. Czech Statistical Office|CZSO. [online] Available at: <https://www.czso.cz> [Accessed 6 December 2020].

Czech Statistical Office (CZSO), 2020b. Klasifikace zaměstnání (CZ-ISCO) | $\check{C} S U ́$. [online] Available at: <https://www.czso.cz/csu/czso/klasifikacezamestnani-cz-isco-n-f4yhpe3xt8> [Accessed 11 December 2020].

Doucek, P., Nedomova, L. and Maryska, M., 2015. Is it Attractive to be the ICT Professional in the Czech Economy? In: IDIMT-2015 (Information Technology and Society Interaction and Interdependence), 23th Interdisciplinary Information Management Talks. Poděbrady, Czech Republic, 09-11 September 2015. Linz: Trauner Verlag Universität, pp. 73-88.

Hanclova, J., Doucek, P., Fischer, J. and Vltavska, K., 2014. Does ICT capital affect economic growth in the EU-15 and EU-12 countries? Journal of Business Economics and Management, [e-journal] 16(2), pp.387-406. DOI: 10.3846/16111699.2012.754375.

Malá, I., 2015. Vícerozměrný pravděpodobnostní model rozdělení př́ijmů českých domácností. Politická ekonomie, 63(7), pp.895-908.

Marek, L. and Doucek, P., 2016. Vývoj mezd a př́ijmové nerovnosti u ICT odborníků v České republice. Politická ekonomie, [e-journal] 64(8), pp.922-938. DOI: $10.18267 /$ j.polek.1118.

Mařík V., 2016. Průmysl 4.0 Výzva pro Českou republiku. Praha, Czech Republic: Management Press.

Mysikova, M. and Vecernik, J., 2018. Personal Earnings Inequality and Polarization: The Czech Republic in Comparison with Austria and Poland. Eastern European Economics, [e-journal] 56(1), pp.57-80. DOI: 10.1080/00128775.2017.1402685.

Národná banka Slovenska (NBS), 2020. Národná banka Slovenska. [online] Available at: 〈https://www.nbs.sk> [Accessed 6 December 2020].

Simard, C., Davies Henderson, A., Gilmartin, S.K., Schiebinger, L. and Whitney, T., 2014. Climbing the Technical Ladder: Obstacles and Solutions for Mid-Level Women in Technology. Anita Borg Institute for Women and Technology and Michelle R. Clayman Institute for Gender Research at Stanford University. Available at: <https://gender.stanford.edu/sites/g/files/sbiybj5961/f/ publications/climbing_the_technical_ladder.pdf> [Accessed 11 December 2019]. 
Statistical Office of the Slovak Republic (SUSR), 2020. Štatistický úrad SR. [online] Available at: <https://slovak.statistics.sk/> [Accessed 6 Decemer 2020].

Suri, K., Cadavid, J., Alferez, M., Dhouib, S. and Tucci-Piergiovanni, S., 2017. Modeling Business Motivation and Underlying Processes for RAMI 4.0-Aligned Cyber-Physical Production Systems. In: IEEE, 22nd IEEE International Conference on Emerging Technologies and Factory Automation. Limassol, Cyprus, 12-15 September 2017. New York, USA: IEEE. DOI: 10.1109/ETFA.2017.8247702.

Torrent-Sellens, J., 2008. La empresa red: tecnologías de la información y la comunicación, productividady competitividad. Barcelona: Ariel, Spain.

Tseng, M.-L., Tan, R.R., Chiu, A.S.F., Chien, C.-F. and Kuo, T.C., 2018. Circular Economy meets Industry 4.0: Can Big Data Drive Industrial Symbiosis? Resource, Conservation and Recycling, [e-journal] 131, pp. 146-147 DOI: 10.1016/j.resconrec.2017.12.028.

Wang, Y., Towara, T. and Anderl, R., 2017. Topological Approach for Mapping Technologies in Reference Architectural Model Industrie 4.0 (RAMI 4.0). In: C. Craig Douglas and W.S. Grundfest eds., $25^{\text {th }}$ World Congress on Engineering and Computer Science 2017. San Francisco, USA, 25-27 October 2017. pp.982-990, DOI: 10.1007/978-981-13-2191-7.

\section{ABOUT AUTHORS}

Lubos Marek ${ }^{0000-0003-4761-1936}$ (L.M.) - Department of Statistics and Probability at the Prague University of Economic and Business, Prague, Czech Republic, e-mail: marek@vse.cz.

Petr Doucek $k^{0000-0002-5647-661 X}$ (P.D.) - Prof., Head of the Department of System Analysis, full professor in Informatics, Prague University of Economic and Business, Prague, Czech Republic, e-mail: doucek@vse.cz.

Lea Nedomová0000-0002-8499-959X (L.N.) - Department of System Analysis at the Faculty of Informatics and Statistics, Prague University of Economic and Business, Prague, Czech Republic, e-mail: nedomova@ vse.cz.

\section{AUTHOR CONTRIBUTIONS}

Conceptualization, P.D. and L.M.; Methodology, L.M.; software, L.M.; Validation, L.M. and P.D.; Formal analysis, L.N.; Investigation, L.M.; Resources, L.N.; Data curation, L.M.; Original draft preparation, P.D., L.M and L.N.; Review and editing, L.N.; Visualization, L.N.; Supervision, P.D.; Project administration, L.N.; Funding acquisition, P.D. 


\section{CONFLICTS OF INTEREST}

The authors declare no conflict of interest. The funders had no role in the design of the study; in the collection, analyses, or interpretation of data; in the writing of the manuscript, or in the decision to publish the results.

(C) 2021 by the authors. Submitted for possible open access publication under the terms and conditions of the Creative Commons Attribution (CC-BY) license (http://creativecommons.org/licenses/by/4.0/). 